\title{
Updated Global Fuel Exploitation Inventory (GFEI) for methane emissions from the oil, gas, and coal sectors: evaluation with inversions of atmospheric methane observations
}

5 Tia R. Scarpelli ${ }^{1,2, *}$, Daniel J. Jacob ${ }^{1}$, Shayna Grossman ${ }^{2}$, Xiao Lu ${ }^{1,3}$, Zhen $\mathrm{Qu}^{1}$, Melissa P. Sulprizio $^{1}$, Yuzhong Zhang ${ }^{4,5}$, Frances Reuland ${ }^{6}$, Deborah Gordon ${ }^{7}$

${ }^{1}$ School of Engineering and Applied Science, Harvard University, Cambridge, MA, USA

${ }^{2}$ Department of Earth and Planetary Sciences, Harvard University, Cambridge, MA, USA

$10{ }^{3}$ School of Atmospheric Science, Sun Yat-sen University, Zhuhai, Guangdong, China

${ }^{4}$ Key Laboratory of Coastal Environment and Resources of Zhejiang Province, School of Engineering, Westlake University, Hangzhou, Zhejiang, China

${ }^{5}$ Institute of Advanced Technology, Westlake Institute for Advanced Study, Hangzhou, Zhejiang, China

${ }^{6}$ Rocky Mountain Institute, Boulder, CO, USA

$15 \quad{ }^{7}$ Rocky Mountain Institute, Providence, RI, USA

*Now at University of Edinburgh, Edinburgh, Scotland

Correspondence to: Tia R. Scarpelli (tia.scarpelli@ed.ac.uk)

20 Abstract. We present an updated version of the Global Fuel Exploitation Inventory (GFEI) for methane emissions and evaluate it with results from global inversions of atmospheric methane observations from satellite (GOSAT) and in situ platforms (GLOBALVIEWplus). GFEI allocates methane emissions from oil, gas, and coal sectors and subsectors to a $0.1^{\circ} \times 0.1^{\circ}$ grid by using the national emissions reported by individual countries to the United Nations Framework Convention on Climate Change (UNFCCC) and mapping them to infrastructure locations. Our updated GFEI v2 gives annual emissions for 2010-2019 that incorporate the most recent UNFCCC national reports, new oil/gas well locations, and improved spatial distribution of emissions for Canada, Mexico, and China. Russia's oil/gas emissions decrease by $83 \%$ in its latest UNFCCC report while Nigerian emissions increase sevenfold, reflecting changes in assumed emission factors. Global gas emissions in GFEI v2 show little net change from 2010 to 2019 while oil emissions decrease and coal emissions slightly increase. Global emissions in GFEI v2 are lower than the EDGAR v6 and IEA inventories for all sectors though there is considerable variability in the comparison for individual countries. GFEI v2 estimates higher emissions by country than the Climate TRACE inventory with notable exceptions in Russia, the US, and the Middle East. Inversion results using GFEI as a prior estimate confirm the lower Russian emissions in the latest UNFCCC report but Nigerian emissions are too high. Oil/gas emissions are generally underestimated by the national inventories for the highest emitting countries including the US, Venezuela,

Uzbekistan, Canada, and Turkmenistan. Offshore emissions in GFEI tend to be overestimated. Our updated GFEI v2 provides a platform for future evaluation of national emission inventories reported to the UNFCCC using the newer generation of satellite instruments such as TROPOMI with improved coverage and spatial resolution. It responds to recent aspirations of the Intergovernmental Panel on Climate Change (IPCC) to integrate top-down and bottom-up information into the construction of national emission inventories. 


\section{Introduction}

Countries under the Paris Agreement must set goals for mitigating greenhouse gas emissions through nationally determined contributions (NDCs). The NDCs often include mitigation targets for methane based on national inventories of current methane emissions from different sectors (COP 2021; COP 2016). These national methane emission inventories are submitted to the United Nations Framework Convention on Climate Change (UNFCCC) and form the framework for methane climate policy. But they may have large uncertainties, particularly for the oil/gas sector. These uncertainties are particularly relevant to current climate policy as many world countries commit to a 30\% reduction in methane emissions by 2030 (European Commission, 2021), including major oil/gas producers like the United States (US), Canada, Nigeria, and Iraq.

50 Inverse analyses of atmospheric methane observations offer an independent check on the inventories (Bergamaschi et al., 2009) but require spatially resolved inventory information that is generally not available from UNFCCC reports. Here we provide this information in a global gridded $\left(0.1^{\circ} \times 0.1^{\circ}\right)$ representation of the UNFCCC-reported national emission inventories for fuel exploitation (oil, gas, and coal) emissions in 2010-2019, updating our previous work for 2016 (Scarpelli et al., 2020a). We compare these national inventories to recent inversions of satellite (GOSAT) and in situ (GLOBALVIEWplus) atmospheric methane observations, and draw implications for improving the inventories.

Oil/gas activities are currently estimated to account for $22 \%\left(84 \mathrm{Tg} \mathrm{a}^{-1}\right.$, range $\left.72-97 \mathrm{Tg} \mathrm{a}^{-1}\right)$ of global anthropogenic methane emissions in 2017 according to emission inventories compiled by the Global Carbon Project (Saunois et al.,

60 2020). The potential for economical mitigation makes the oil/gas sector an attractive target for emission reductions (Alvarez et al., 2018). Individual countries report oil/gas methane emissions to the UNFCCC as part of their national inventories using 'bottom-up' methods that apply emission factors (e.g., mass of methane emitted per unit volume of oil produced) to source activity data (e.g., volume of oil produced per year). Annex I countries must report emissions every year by oil/gas subsector (e.g., oil production). Non-Annex I countries are not required to report emissions every year or by subsector, and many use default emission factors from the Intergovernmental Panel on Climate Change (IPCC, 2006; 2019). Emission factors may vary considerably and the corresponding uncertainties carry over to the national inventory (Scarpelli et al., 2020a).

'Top-down' information from observations of atmospheric methane can help to evaluate and improve the bottom-up national inventories (IPCC, 2019). This is generally done by inverse modeling where an atmospheric transport model is used to relate methane emissions to atmospheric concentrations (Houweling et al., 2017). The top-down information on emissions comes from observed atmospheric concentration gradients, hence the need for prior information from a spatially resolved inventory. The atmospheric observations and the transport model are prone to their own errors. An optimal estimate of emissions can be determined by error-weighted Bayesian inference combining the information from atmospheric observations with that from the bottom-up inventory (Jacob et al., 2016). 
National inventories submitted to the UNFCCC do not in general provide the spatial resolution needed for the exploitation of top-down information. An exception is the United Kingdom (UK) which provides a finely gridded yearly inventory (Defra and BEIS, 2021). A number of studies have spatially allocated national inventories for specific years to enable inversions of atmospheric data including for Australia (Wang and Bentley, 2002), Switzerland (Hiller et al., 2014), the US (Maasakkers et al., 2016), Mexico (Scarpelli et al., 2020b), and Canada (Scarpelli et al., 2021a). Scarpelli et al. (2020a) constructed the Global Fuel Exploitation Inventory (GFEI) for 2016 that spatially allocates national oil, gas, and coal methane emissions reported to the UNFCCC to a $0.1^{\circ} \mathrm{x} 0.1^{\circ}$ grid, and supplements information for non-reporting countries. This inventory has been used as prior estimate in a number of inversions (Zhang et al., 2021; Shen et al., 2021; Lu et al., 2021; Qu et al., 2021; Western et al., 2021).

Here we update GFEI to 2019 (Scarpelli et al., 2021b) using more recent national emissions submitted to the UNFCCC (2021), describe the 2010-2019 national emission trends based on the UNFCCC reports, and interpret the results from global inversions of atmospheric methane observations using GFEI as prior estimate. We use the bottom-up information embedded in GFEI, including infrastructure locations, to identify the processes that drive discrepancies between the bottom-up and inversion estimates. Our work provides a step towards the aspiration of IPCC (2019) to integrate top-down and bottom-up information in the construction of national inventories for climate policy.

\section{Updated Global Fuel Exploitation Inventory (GFEI v2)}

\subsection{GFEI v1}

Scarpelli et al. (2020a) constructed the Global Fuel Exploitation Inventory version 1 (GFEI v1) at $0.1^{\circ} \mathrm{x} 0.1^{\circ}$ grid resolution by disaggregating the national UNFCCC methane emission reports to oil/gas/coal emission subsectors and then allocating subsector emissions to the appropriate infrastructure locations within each country including wells, processing plants, compressor stations, pipelines, storage facilities, refineries, and coal mines. GFEI v1 was constructed for 2016 and includes separate gridded emission data for each oil/gas subsector and emission process (leakage, venting, flaring). Annex I countries report emissions to the UNFCCC annually and by subsector so these emissions are used as reported. Non-Annex I countries are only required to report total emissions by sector and do not report every year. Scarpelli et al. (2020a) partitioned non-Annex I emissions by subsector and updated emissions to 2016 using a combination of IPCC emission factors (IPCC, 2006) and oil/gas activity data from the US Energy and Information Administration (EIA). They also incorporated more detailed emission estimates, when available, from the most recent National Communications and Biennial Update Reports of the top-emitting (above $1 \mathrm{Tg} \mathrm{a}^{-1}$ ) non-Annex I countries. In North America, GFEI v1 used the gridded inventories from Sheng et al. (2017) for oil/gas in Canada and Mexico, and Maasakkers et al. (2016) for oil/gas/coal in the US, to distribute the UNFCCC-reported national emissions. 


\subsection{Construction of GFEI v2}

Here we update GFEI to provide annual emissions for 2010-2019 using the most recent national reports to the UNFCCC as of September 2021 combined with new infrastructure information. We refer to this updated inventory as version 2 (v2; Scarpelli et al., 2021b). For GFEI v2, we do not use UNFCCC national reports if the most recent report is dated prior to 2000 which most notably includes Iraq. The UNFCCC (2020) data include yearly emissions from Annex I countries for 2010-2019, and updated emissions for a number of non-Annex I countries. We use updated EIA (2021) activity data to partition non-Annex I emissions to subsectors as necessary and to adjust emissions to the desired year. For the top-emitting non-Annex I countries (emissions above $1 \mathrm{Tg} \mathrm{a}^{-1}$ ), we continue to use additional emissions information from National Communications and Biennial Update Reports submitted to the UNFCCC. This includes Nigeria, for which emissions were below $1 \mathrm{Tg} \mathrm{a}^{-1}$ in GFEI v1 but are much higher in the most recent National Communication to the UNFCCC (Federal Republic of Nigeria, 2020).

We start from the same spatial infrastructure information as Scarpelli et al. (2020a) but update well locations using the most recent data from Enverus (2019). We allocate downstream (distribution) gas emissions using an updated population density map for 2015 (CIESIN, 2017). For coal emissions allocation, we use the 2018 gridded emissions from EDGAR version 6 (Crippa et al., 2021; European Commission, 2021) with the exception of the UK where we use EDGAR v4.3.2 (Janssens-Maenhout et al., 2019; European Commission, 2017) as there are no UK coal sources in more recent versions of EDGAR. We use improved bottom-up information for the distribution of emissions in Mexico (Scarpelli et al., 2020b), Canada (Scarpelli et al., 2021a), and coal in China (Sheng et al., 2019).

Annex I countries report 'other' oil/gas emissions which Scarpelli et al. (2020a) allocated 50\% to wells and 50\% to pipelines. For GFEI v2, we distribute 'other' emissions to oil/gas subsectors and their corresponding infrastructure relative to the contribution of each subsector to total oil/gas emissions. The US and Canada are exceptions where we instead attribute all 'other' oil/gas emissions to oil/gas production based on national inventories (EPA, 2020;

135 Scarpelli et al., 2021).

\subsection{GFEI v2 methane emissions}

Figure 1 shows GFEI v2 methane emissions at $0.1^{\circ} \mathrm{x} 0.1^{\circ}$ grid resolution for 2019 , totaling $26 \mathrm{Tg} \mathrm{a}^{-1}$ for oil, $22 \mathrm{Tg} \mathrm{a}^{-}$ ${ }^{1}$ for gas, and $33 \mathrm{Tg} \mathrm{a}^{-1}$ for coal. Global emissions by sector and oil/gas subsector are compiled in Table 1. Figure 2 shows emissions for the top emitting countries with China, the US, and Russia together accounting for $39 \%$ of global gas emissions and $79 \%$ of global coal emissions while oil emissions more distributed among the top emitting countries. GFEI v2 oil and gas production emissions are 32\% and 15\% lower, respectively, than in GFEI v1 (Table 1), mainly because of downward revision of Russia's national emissions in its latest UNFCCC (2021) report. Global coal emissions do not change significantly between $\mathrm{v} 1$ and $\mathrm{v} 2$ for the same year. 

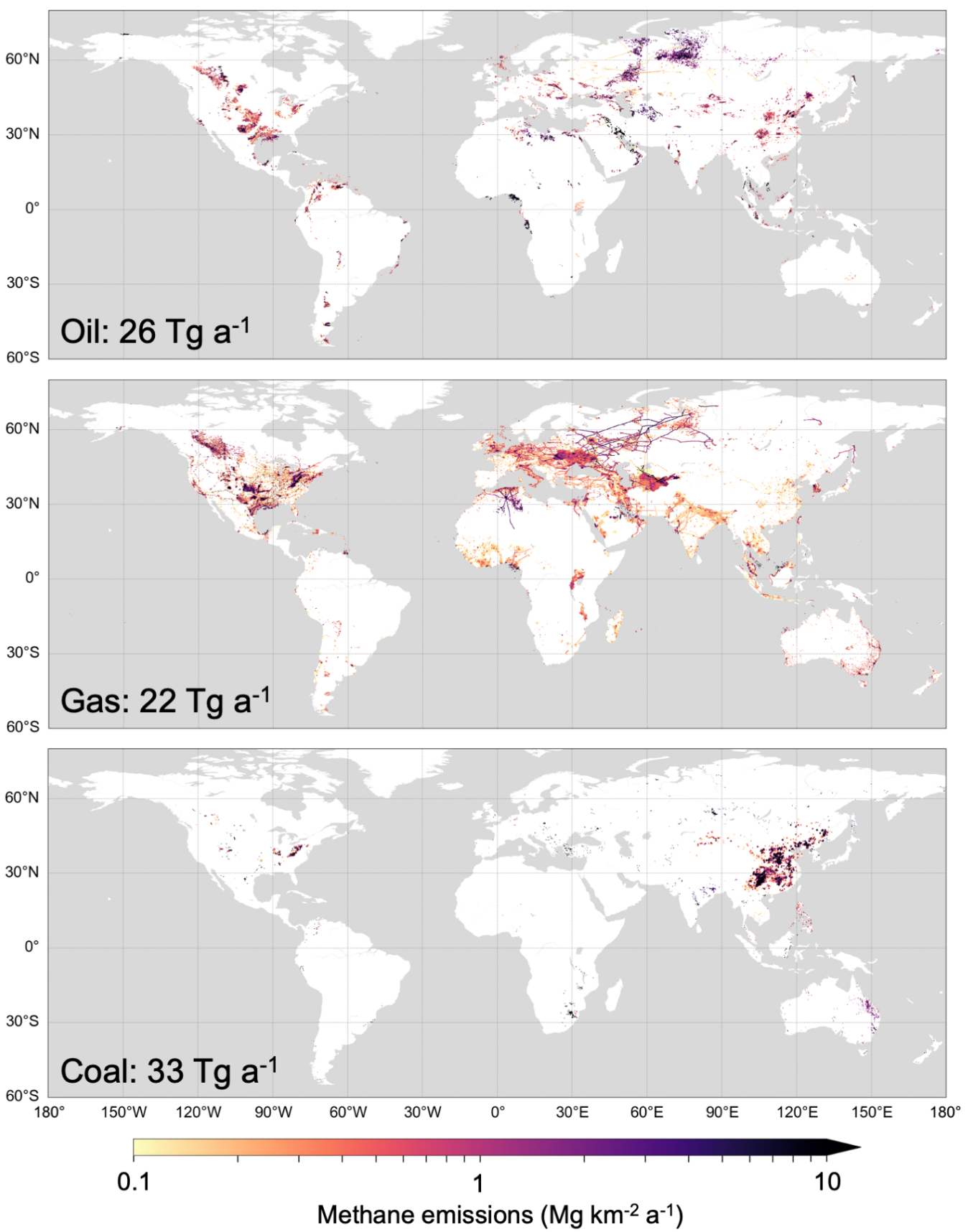

Figure 1. Methane emissions from oil, gas, and coal exploitation in GFEI v2 for 2019. Emissions are at $0.1^{\circ} \mathrm{x} 0.1^{\circ}$ grid resolution with global emissions inset. Emissions below $0.1 \mathrm{Mg} \mathrm{km}^{-2} \mathrm{a}^{-1}$ are not shown. 

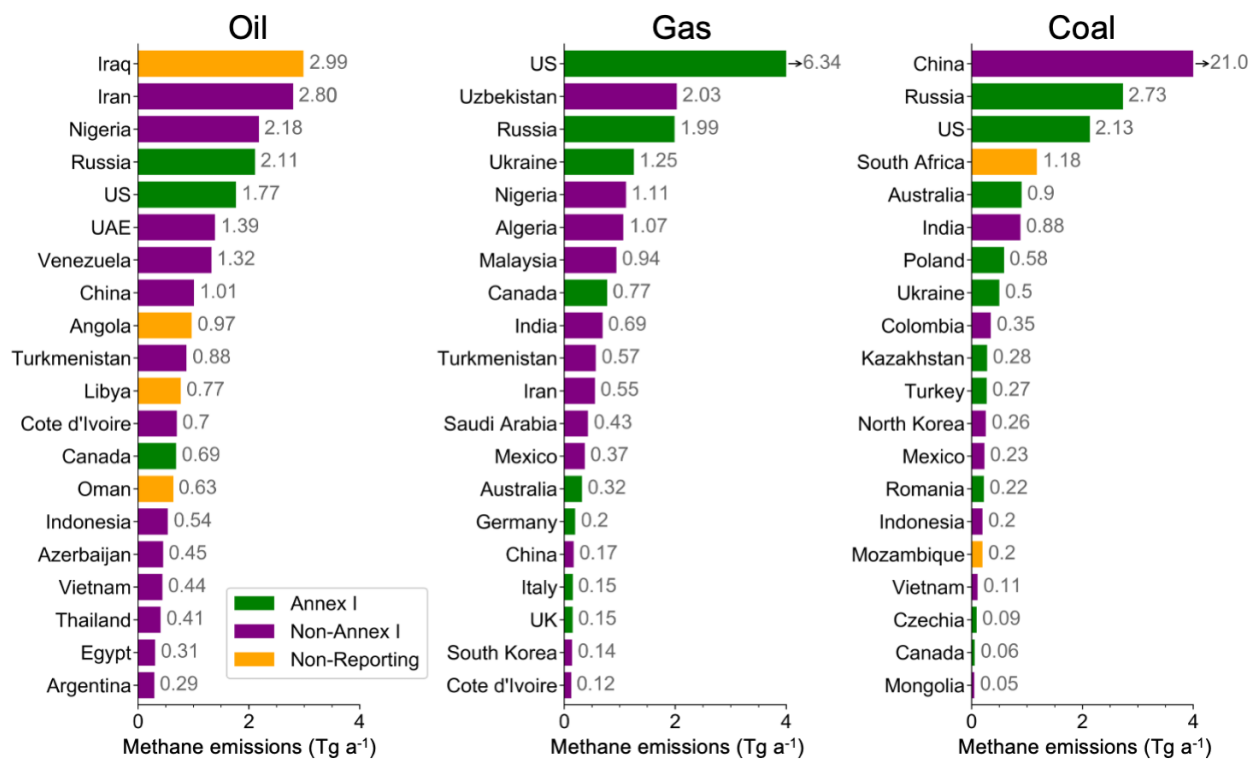

Figure 2. Oil, gas, and coal methane emissions by country for 2019 from GFEI v2. Emissions are shown for the top 20 emitting countries. Arrows next to the top bars (highest emitting countries) indicate that emissions are not to scale. US - United States; UAE - United Arab Emirates; UK - United Kingdom.

Table 1. Global methane emissions from oil, gas, and coal exploitation $\left(\mathrm{Tg} \mathrm{a}^{-1}\right)$

\begin{tabular}{|c|c|c|c|c|c|}
\hline & $\begin{array}{l}\text { GFEI v2 } \\
2019\end{array}$ & $\begin{array}{l}\text { GFEI v2 } \\
2016\end{array}$ & $\begin{array}{l}\text { GFEI v1 }^{\mathrm{a}} \\
2016\end{array}$ & $\begin{array}{l}\text { Lu et al. }(2021)^{b} \\
2010-2017\end{array}$ & $\begin{array}{c}\text { Qu et al. }(2021)^{b} \\
2019\end{array}$ \\
\hline Oil/gas & 47.6 & 48.9 & 65.9 & $68.5(0.5)$ & $54.4(0.3)$ \\
\hline Oil & 25.8 & 28.1 & 41.5 & $38.8(0.5)$ & $27.4(0.3)$ \\
\hline Production ${ }^{\mathrm{c}}$ & 25.5 & 27.8 & 41.3 & $38.6(0.5)$ & $27.2(0.3)$ \\
\hline Transport/Refining & 0.3 & 0.3 & 0.2 & $0.2(0.0)$ & $0.2(0.0)$ \\
\hline Gas & 21.8 & 20.8 & 24.4 & $29.7(0.4)$ & $26.9(0.2)$ \\
\hline Production $^{\mathrm{c}}$ & 8.1 & 7.8 & 7.5 & $10.4(0.5)$ & $9.1(0.2)$ \\
\hline Processing & 2.2 & 2.0 & 2.4 & $3.3(0.5)$ & $3.6(0.2)$ \\
\hline Transmission $^{\mathrm{d}}$ & 5.3 & 5.5 & 8.7 & $9.1(0.1)$ & $7.7(0.1)$ \\
\hline Distribution & 6.2 & 5.5 & 5.7 & $6.9(0.1)$ & $6.5(0.1)$ \\
\hline Coal & 32.8 & 30.5 & 31.3 & $23.7(0.5)$ & $26.0(0.3)$ \\
\hline
\end{tabular}

\footnotetext{
${ }^{\mathrm{a}}$ Scarpelli et al. (2020a).
}

${ }^{\mathrm{b}}$ Posterior emission estimates from inversions of atmospheric methane observations using GFEI v1 for 2016 as a prior estimate.

Averaging kernel sensitivities in parentheses are the diagonal terms of the reduced averaging kernel matrix $\boldsymbol{A}^{\prime}$ (equation 2). They extend from 0 (no information from the atmospheric methane observations) to 1 (fully informed by the observations).

${ }^{\mathrm{c}}$ Including exploration.

${ }^{\mathrm{d}}$ Including storage.

changes to the distribution of emissions within the countries. The use of the Sheng et al. (2019) inventory for the

165 distribution of China's coal emissions leads to higher emissions in the south and lower in the north, in part due to the inclusion of provincial emission factors (Sheng et al., 2019). The main countries that revised their UNFCCC emissions between GFEI v1 and v2 are the US, Uzbekistan, Nigeria, and Russia. GFEI v2 oil/gas emissions in the 
US (7.8 $\mathrm{Tg} \mathrm{a}^{-1}$ for 2016) are 7\% lower than GFEI v1, mainly because of downward revision for the gas production subsector. This downward revision reflects the incorporation of facility-reported oil/gas emissions from the US Greenhouse Gas Reporting Program (GHGRP) and the use of new emission factors based on US GHGRP data and field measurements (EPA, 2020; EPA, 2021). Iraq's emissions have also significantly changed in GFEI v2 due to the use of IPCC Tier 1 methods to estimate its emissions rather than the pre-2000 UNFCCC reported emissions as used in GFEI v1.

Figure 3 shows national emission factors for oil/gas production as implied by GFEI v2 in combination with EIA oil/gas production statistics. These emission factors vary by five orders of magnitude between countries. Also shown is the range of emission factors provided by IPCC (2006) guidelines, ranging from the lowest value for Developed Countries to the highest value for Developing Countries and Countries with Economies in Transition. The IPCC (2006) emission factors vary by over two orders of magnitude and most countries fit within that range. The IPCC (2006) emission factors for gas production equate to leakage rates of 0.06 to $3.8 \%$, assuming $92 \%$ methane gas by volume.
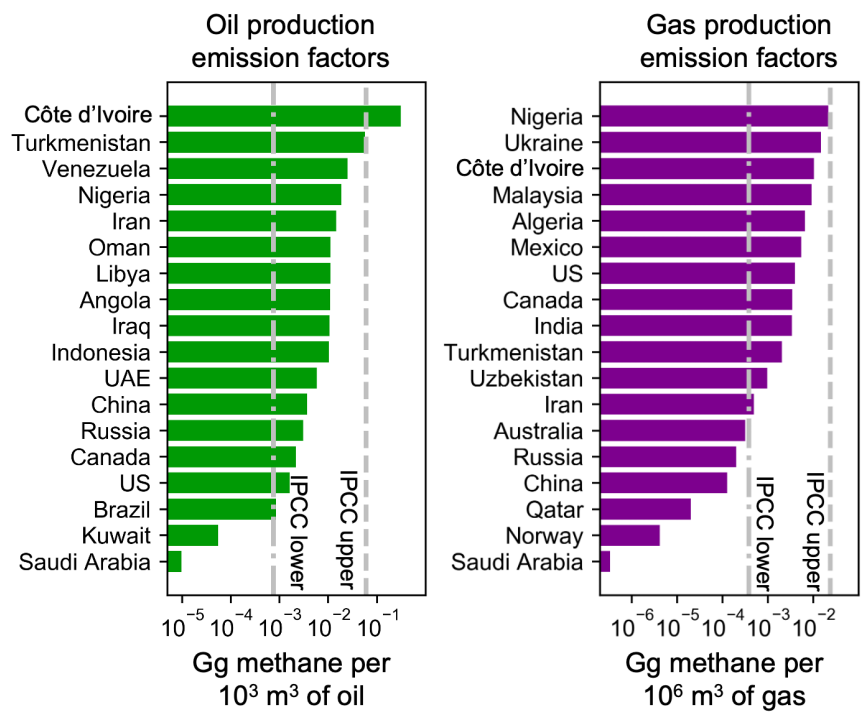

Figure 3. Methane emission factors for oil/gas production activities in 2019. Emission factors are shown for the top methane emitting and oil/gas producing countries, and for the IPCC Tier 1 methods (2006). Country emission factors are determined using GFEI v2 oil/gas production emissions and EIA oil/gas production statistics. The IPCC emission factors show the sum of all emission processes (leakage, venting, flaring) with the lower emission factor reflecting the lowest range provided for Developed Countries and the upper emission factor reflecting the highest range provided for Developing Countries and Countries with Economies in Transition. For oil production, we show emission factors for conventional oil production. US - United States; UAE - United Arab Emirates.

The low emission factors shown in Fig. 3 for some Middle East countries could reflect modern infrastructure, high rates of production per well, and widespread associated gas capture and high efficiency flaring. The dominance of offshore production in countries like Norway and Qatar may also contribute to low emission factors. The order of magnitude decrease in Russian oil emissions and increase in Nigerian oil emissions between GFEI v1 and v2 (Table 

upper limit of the IPCC (2006) range in its most recent report to the UNFCCC (Federal Republic of Nigeria, 2020).

Russia previously used the IPCC (2006) emission factors for Developing Countries and Countries with Economies in Transition (Russian Federation, 2018), but in its most recent report (Russian Federation, 2021) it uses the IPCC (2006) emission factors for Developed Countries and country-specific emission factors based on measurements (mostly limited to gas activities). The methodology update is, in part, based on increases in gas use for energy and rules limiting associated gas flaring (Russian Federation, 2021). Previous inverse studies found that oil/gas emissions in the older Russian national inventory were too high (Maasakkers et al., 2019; Zhang et al., 2021), supporting the decrease in the revised inventory.

Figure 4 shows GFEI v2 emission trends over 2010-2019. These trends are determined using emissions as reported to the UNFCCC (2021) for Annex I countries (in Fig. 4 this includes Russia, the US, and Ukraine) and otherwise using EIA activity data to scale annually the reported inventory years. Global oil emissions show a decrease over 2010-2013 driven by Libya and Iran and over 2017-2019 driven by Venezuela. This global emissions decrease is in 210 contrast to a $14 \%$ increase in global oil production (EIA, 2020), and reflects compensation between decreased production in countries with high emission factors like Venezuela and Iran, and increased production in countries with low emission factors like Brazil and Kuwait (Fig. 3).

Global gas emissions decrease over 2011-2017, mostly driven by Russia, and then increase in 2018 and 2019 due to 215 contributions from various countries, including Uzbekistan, the US, and Ukraine. Global coal emissions slightly increase from 2010 to 2019 with large interannual variability mainly driven by China (based on EIA activity data). Coal emissions show a steady decrease in the US and an increase in Russia.

Figure 5 shows global oil, gas, and coal emissions for GFEI along with the most recent estimates from the EDGAR v6 inventory (Crippa et al., 2021; European Commission, 2021) and from the International Energy Agency (IEA) inventory (IEA, 2021). The IEA inventory does not include coal emissions. GFEI v1 has higher oil emissions than the other bottom-up inventories, mostly attributable to the high Russian emissions mentioned previously. Global emissions in EDGAR and IEA are higher than GFEI v2 for all sectors but with considerable variability between countries including in the sign of the difference as shown in Fig. S2.

\section{Information from inverse analyses}

Here we examine results from two recent global inversions of atmospheric methane observations that used GFEI v1 as a prior estimate of emissions (Lu et al., 2021; Qu et al., 2021), to determine what insights can be gained toward improving the bottom-up inventories and arbitrating the differences between the inventories. We focus our 


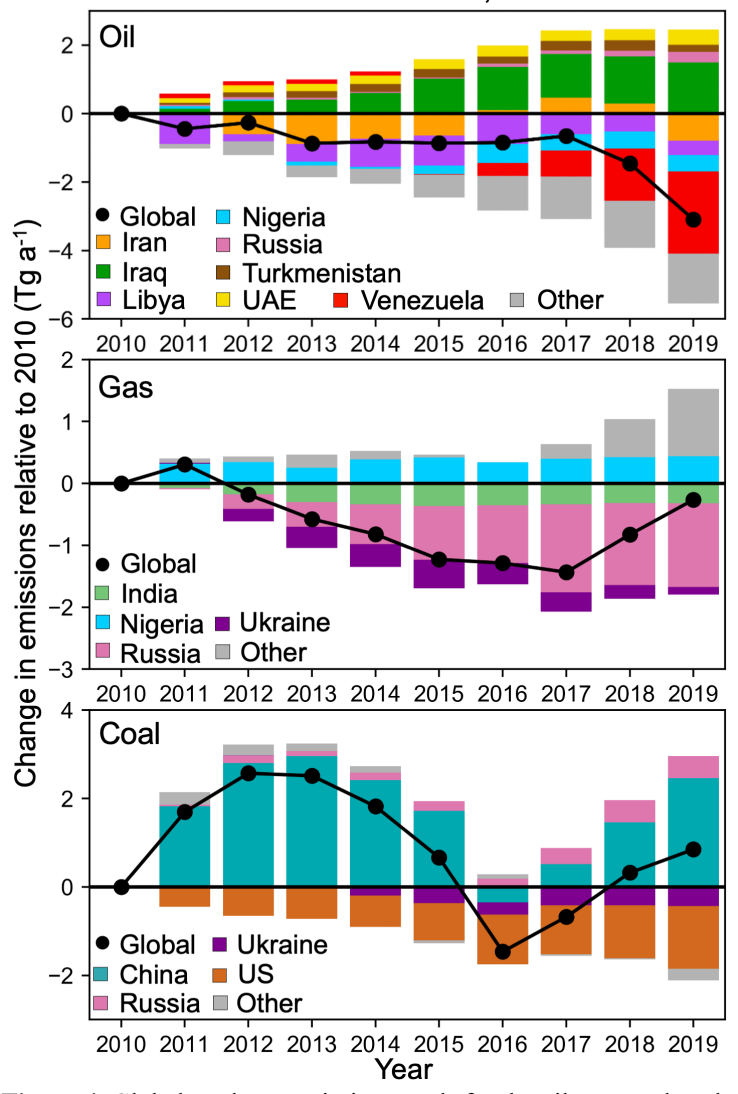

230 Figure 4. Global methane emission trends for the oil, gas, and coal sectors from 2010 to 2019 in GFEI v2, expressed relative to 2010. Trends for individual countries contributing the most to the global trends are also shown. US - United States; UAE - United Arab Emirates.

discussion on oil/gas emissions because of the difficulty for these inversions to quantify coal emissions in China (Qu

235 et al., 2021). This difficulty is due in part to poor spatial allocation of Chinese emissions since corrected in GFEI v2 (Sheng et al., 2019).

\subsection{Methods}

Lu et al. (2021; referred to hereafter as Lu21) and Qu et al. (2021; referred to hereafter as Qu21) used similar inversion procedures but applied them to different observations, time periods, and spatial resolution. They also used different prior estimates for some emission sources (e.g., wetlands). Both inversions used GEOS-Chem as the forward chemical transport model. Both optimized a state vector $\boldsymbol{x}$ including annual non-wetland emissions on the GEOS-Chem grid, monthly wetland emissions for 14 subcontinental regions (Bloom et al., 2017), and the mean concentration of tropospheric $\mathrm{OH}$ (the main methane sink) in each hemisphere. Lu21 optimized mean non-wetland methane emissions for 2010-2017 and their linear temporal trends on a $4^{\circ}$ x $5^{\circ}$ grid. They used 2010-2017 GOSAT satellite observations of methane columns (Parker et al., 2020) and an ensemble of surface, aircraft, and ship 
observations compiled as the GLOBALVIEWplus $\mathrm{CH}_{4}$ ObsPack v1.0 database (NOAA ESRL, 2019). Qu21 optimized non-wetland methane emissions for 2019 on a $2^{\circ}$ x $2.5^{\circ}$ grid using 2019 GOSAT and TROPOMI satellite observations of methane columns separately and together. The TROPOMI observations in Qu21 were from the early-generation retrieval of $\mathrm{Hu}$ et al. (2018) and showed some major regional biases that propagated to the inversion results. Here we focus on their GOSAT-only inversion results. Lu21 excluded GOSAT observations over the oceans (glint) and both inversions excluded observations poleward of $60^{\circ}$. Gridded non-wetland emissions were assumed to have a prior error standard deviation of 50\%. For wetland emissions, Lu21 and Qu21 used prior error variances and covariances from Bloom et al. (2017), but Qu21 found that they needed to greatly decrease these errors (by a factor of 24) to regularize their inversion of TROPOMI data and they applied the same low prior errors for wetlands in their inversion of GOSAT data.

Both Lu21 and Qu21 used the same analytical solution to minimization of the Bayesian cost function in order to produce their posterior emission estimates (Jacob et al., 2016). The analytical solution provides not only a maximum-probability posterior estimate $\widehat{\boldsymbol{x}}$ for the state vector, but also a closed-form posterior error covariance matrix $(\widehat{S})$ for that state vector from which we can determine the information content of the inversion using the averaging kernel matrix $\left(\boldsymbol{A}=\boldsymbol{I}-\widehat{\boldsymbol{S}} \boldsymbol{S}_{A}{ }^{-1}\right.$, where $\boldsymbol{S}_{A}$ is the prior error covariance matrix). The diagonal terms of $\boldsymbol{A}$ represent the averaging kernel sensitivities $\left(a_{j}\right)$ that characterize the ability of the atmospheric observations to determine emissions from grid cell $j$ independently of the prior estimate (perfectly if $a_{j}=1$, not at all if $a_{j}=0$ ). The trace of $\boldsymbol{A}$ defines the degrees of freedom for signal (DOFS), representing the number of independent pieces of information on methane emissions that can be obtained from the observations (Rodgers, 2000).

The contributions of oil/gas sectors and subsectors to the total posterior non-wetland emissions optimized by the inversions can be inferred from the inversion results by applying a summation matrix $(\boldsymbol{W})$ :

$$
\begin{gathered}
\widehat{\boldsymbol{x}}^{\prime}=\boldsymbol{W} \widehat{\boldsymbol{x}}(1), \\
\boldsymbol{A}^{\prime}=\boldsymbol{W} \boldsymbol{A} \boldsymbol{W}^{*}
\end{gathered}
$$

where $\boldsymbol{W}^{*}=\boldsymbol{W}^{T}\left(\boldsymbol{W} \boldsymbol{W}^{T}\right)^{-\mathbf{1}}$ is the pseudo inverse matrix (Calisesi et al., 2005). Here $\widehat{\boldsymbol{x}}^{\prime}$ is a posterior state vector of oil/gas emissions per grid cell, country, or globally; and $\boldsymbol{A}^{\prime}$ is the corresponding averaging kernel matrix. $\boldsymbol{W}$ is constructed by using the prior estimates of the oil/gas sector/subsector contributions to emissions in individual grid cells, and summing those nationally or globally. We use GFEI v1 at the native $0.1^{\circ} \mathrm{x} 0.1^{\circ}$ resolution to better resolve boundaries in estimates of national emissions, but the coarse resolution of the inversions is still a limitation for small countries and for oil/gas emissions near country borders.

280 Figure S3 shows posterior oil/gas emissions and averaging kernel sensitivities for the Lu21 and Qu21 inversions. Lu21 report a global DOFS of 262 for optimizing non-wetland emissions on their $4^{\circ} \times 5^{\circ}$ grid while Qu21 report a DOFS of 232 on their $2^{\circ} \times 2.5^{\circ}$ grid. The higher resolution and low wetland prior errors in Qu21 would be expected 


\subsection{Results and discussion}

Figure 5 shows global oil, gas, and coal emissions from the inversions and Table 1 gives further detail for oil/gas subsectors. Global gas emissions in Lu21 and Qu21 are 23-36\% higher than GFEI v2 with higher emissions for all gas subsectors (Table 1). Averaging kernel sensitivities are high for upstream gas activities (production and processing) but low for gas transmission and distribution. Lu21 and Qu21 estimate much lower gas emissions compared to EDGAR and IEA estimates (Fig. 5), and averaging kernel sensitivities are sufficiently high that this difference cannot be simply attributed to the lower prior estimate. Global oil emissions in Lu21 are slightly lower than GFEI v1 (7\% lower) while Qu21 emissions are much lower (34\%) and in better agreement with GFEI v2, mostly due to decreases in Russian oil emissions. Global oil emissions in EDGAR and IEA are in between the Lu21 and Qu21 estimates.

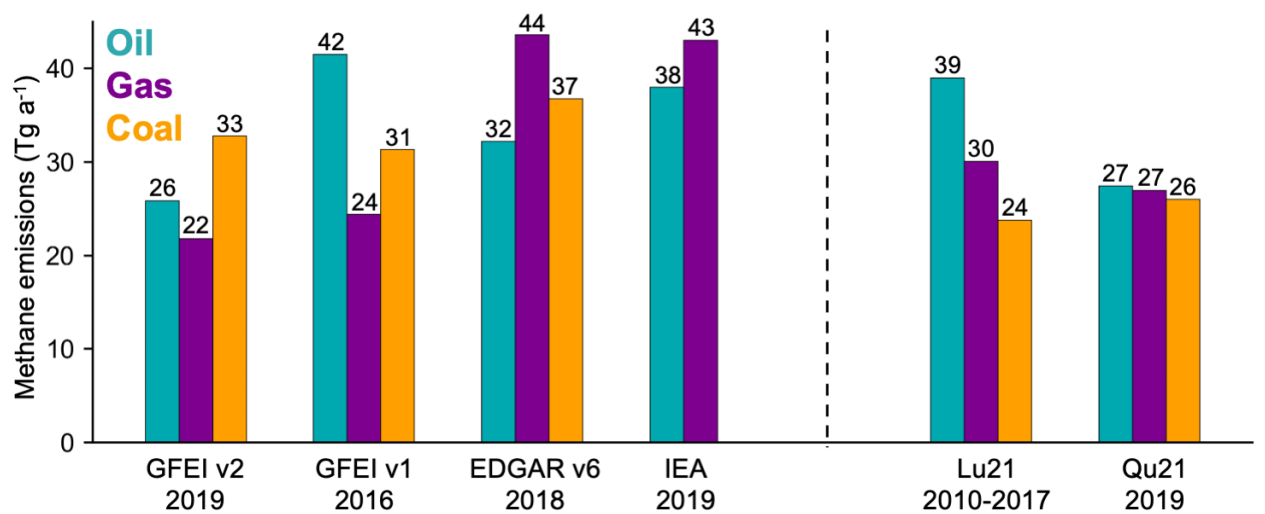

Figure 5. Global estimates of oil, gas, and coal methane emissions. The left bars show bottom-up inventories while the right bars show inversion results from Lu et al. (2021; Lu21) and Qu et al. (2021; Qu21).

300 Figure 6 shows the national oil/gas emissions in the two inversions and the different bottom-up inventories. We also compare to annual country-level oil/gas methane emission estimates in the Climate TRACE inventory (Reuland et al., 2021). Both inversions use GFEI v1 as a prior estimate, so results are directly relevant to evaluating the national reports to the UNFCCC. The averaging kernel sensitivities in Fig. 6 indicate the dependence of the inversion results on the prior estimate $(1=$ totally independent, $0=$ totally dependent). Even when averaging kernel sensitivities are low the sign of the corrections relative to GFEI v1 is informative. There are some large discrepancies between Lu21 and Qu21, generally for countries with low averaging kernel sensitivities in Qu21. An additional concern with Qu21 is the strong prior constraint on wetland emissions that may lead to aliasing of wetland emissions adjustments to oil/gas when there is spatial overlap (such as Russia and Canada). We therefore focus on the Lu21 results but add the perspective from the Qu21 results when appropriate. 


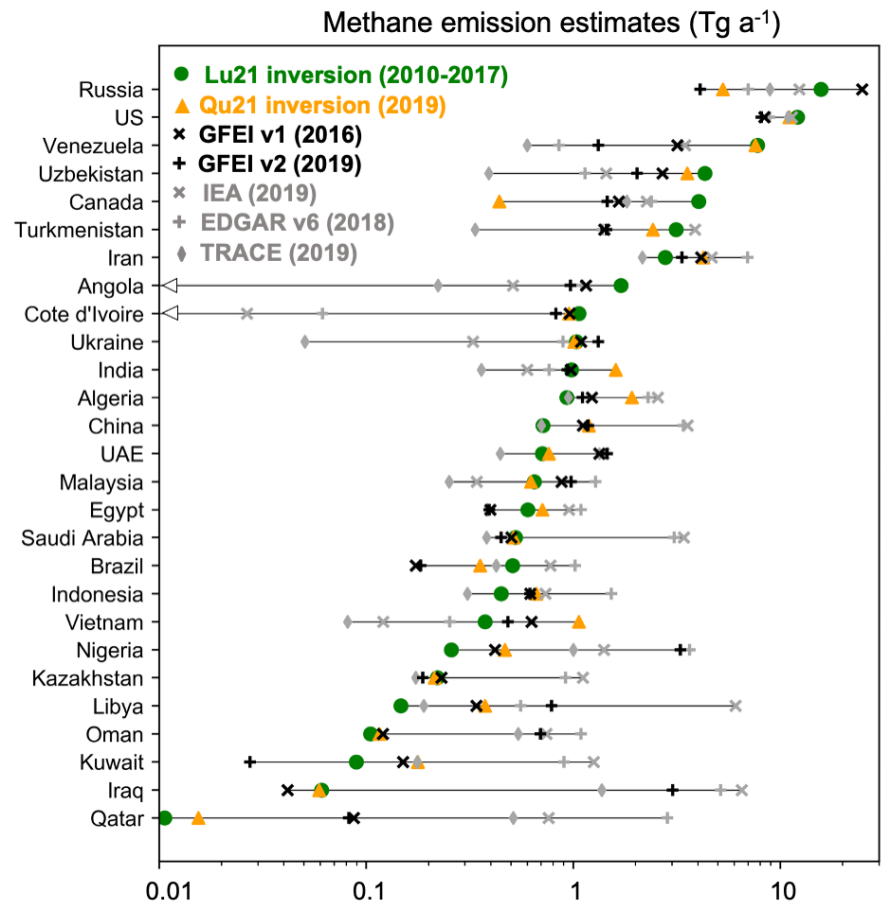

Averaging kernel sensitivities

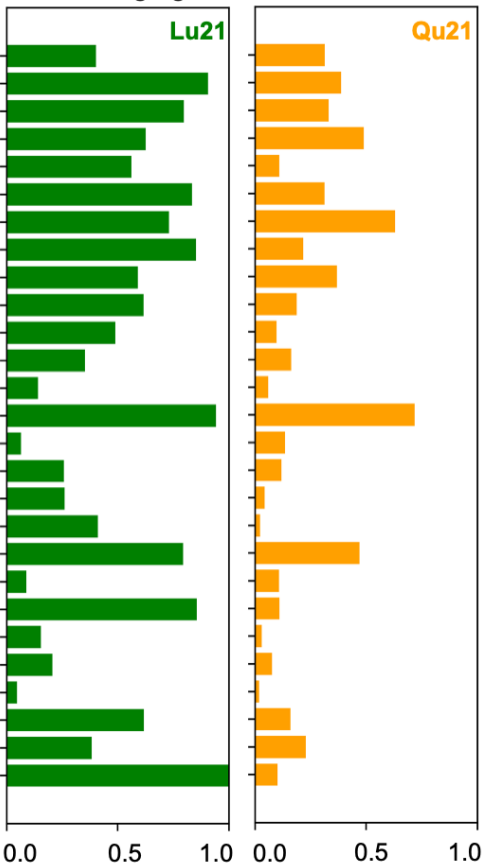

Figure 6. Oil/gas methane emissions in top-emitting countries. The Figure compares bottom-up emissions in the GFEI v1, GFEI v2, EDGAR v5, Climate TRACE, and IEA inventories as well as the inversion results of Lu et al. (2021; Lu21) and Qu et al. (2021; Qu21). Averaging kernel sensitivities for oil/gas emissions in individual countries from the two inversions are also given. The countries shown are those with oil/gas emissions larger than $1 \mathrm{Tg} \mathrm{a}^{-1}$ in any of the emission estimates. Horizontal lines extend from the minimum to the maximum emission estimate unless arrow heads designate that emissions in at least one estimate are below $0.01 \mathrm{Tg} \mathrm{a}^{-1}$. US - United States; UAE - United Arab Emirates.

Table 2 shows Lu21 oil/gas emissions by country for the top-emitting countries which account for $82 \%$ of Lu21 global oil/gas emissions. Upstream oil/gas activities (oil/gas production and gas processing; Table S1 and S2) have the largest emissions contribution. The inversion finds emission underestimates in GFEI v1 and v2 for these topemitting countries including the US, Venezuela, Uzbekistan, Canada, and Turkmenistan, with Russia as the major exception. Correcting emissions in these countries leads to the higher global gas emissions in Lu21 compared to GFEI v1 and v2. The global oil emissions in Lu21 show little change from GFEI v1 because Venezuela's emissions increase is offset by the large decrease in Russian oil emissions.

Russia accounts for $25 \%$ of global oil/gas emissions in the Lu21 inversion, with a national total of $15.8 \mathrm{Tg} \mathrm{a}^{-1}$. This is lower than GFEI v1 (24.9 $\left.\mathrm{Tg} \mathrm{a}^{-1}\right)$, used as prior estimate, but still higher than the other bottom-up inventories including GFEI v2 for $2016\left(4.3 \mathrm{Tg} \mathrm{a}^{-1}\right)$. Averaging kernel sensitivities for Russia are relatively low in the Lu21 inversion because the high latitude oil/gas emissions are difficult to observe. Thus the inversion results are strongly influenced by the high prior estimate from GFEI v1, and are not consistent with the much lower estimate in GFEI v2. The Qu21 inversion gives lower oil/gas emissions for Russia compared to all bottom-up inventories but we 
Table 2. Methane emissions from oil/gas activities by country $\left(\mathrm{Tg} \mathrm{a}^{-1}\right)^{\mathrm{a}}$

\begin{tabular}{|c|c|c|c|c|c|c|}
\hline & \multicolumn{3}{|c|}{ Oil } & \multicolumn{3}{|c|}{ Gas } \\
\hline & $\begin{array}{c}\text { GFEI v2 } \\
2016 \\
\end{array}$ & $\begin{array}{c}\text { GFEI v1 } \\
2016 \\
\end{array}$ & $\begin{array}{c}\text { Lu21 } \\
2010-2017\end{array}$ & $\begin{array}{c}\text { GFEI v2 } \\
2016 \\
\end{array}$ & $\begin{array}{c}\text { GFEI v1 } \\
2016 \\
\end{array}$ & $\begin{array}{c}\text { Lu21 } \\
2010-2017\end{array}$ \\
\hline Russia & 1.9 & 20.5 & 12.7 & 2.4 & 4.4 & 3.1 \\
\hline US & 1.8 & 1.8 & 2.3 & 6.0 & 6.6 & 9.8 \\
\hline Venezuela & 3.3 & 3.2 & 7.7 & 0 & 0 & 0 \\
\hline Uzbekistan & $<0.01$ & $<0.01$ & $<0.01$ & 1.7 & 2.7 & 4.3 \\
\hline Canada & 0.75 & 0.88 & 2.0 & 0.79 & 0.78 & 2.0 \\
\hline Turkmenistan & 0.87 & 0.88 & 1.8 & 0.53 & 0.52 & 1.3 \\
\hline Iran & 3.7 & 3.7 & 2.2 & 0.48 & 0.49 & 0.61 \\
\hline Angola & 1.2 & 1.2 & 1.7 & $<0.01$ & $<0.01$ & $<0.01$ \\
\hline Côte d'Ivoire & 0.72 & 0.85 & 0.94 & 0.12 & 0.11 & 0.13 \\
\hline Ukraine & 0.06 & 0.06 & 0.05 & 1.0 & 1.0 & 0.98 \\
\hline Algeria & 0.05 & 0.05 & 0.05 & 1.1 & 1.2 & 0.89 \\
\hline China & 1.0 & 1.0 & 0.64 & 0.12 & 0.11 & 0.08 \\
\hline UAE & 1.3 & 1.3 & 0.68 & 0.07 & 0.07 & 0.03 \\
\hline Nigeria & 2.1 & 0.19 & 0.10 & 1.0 & 0.23 & 0.16 \\
\hline Iraq & 2.8 & 0.04 & 0.05 & 0.02 & 0.01 & 0.06 \\
\hline
\end{tabular}

335 ail and gas methane emissions by top emitting countries are shown for GFEI v2 for 2016 (this work), GFEI v1 for 2016 (Scarpelli et al., 2020a), and the inversion of Lu et al. (2021; Lu21) for 2010-2017 (8-year average). Emissions by oil/gas subsector are shown in Table S1 and S2. GFEI v2 emissions for 2019 are shown in Fig. 2. US - United States; UAE - United Arab Emirates.

340 suspect that this reflects their non-optimization of wetlands, which have substantial overlap with oil/gas emissions in Russia.

Lu21 find higher oil/gas emissions for the US and Canada compared to GFEI v1 with high averaging kernel sensitivities for both countries. Many past studies in the US have found an underestimate of oil/gas emissions in the

345 US national inventory (Alvarez et al., 2018; Omara et al., 2018; Cui et al., 2019; Maasakkers et al., 2019, 2021;

Rutherford et al., 2021) and similar underestimates have been shown for Canada's national inventory (Johnson et al., 2017; Atherton et al., 2017; Baray et al., 2018, 2021; Chan et al., 2020; Scarpelli et al., 2021; MacKay et al., 2021;

Tyner and Johnson, 2021). These underestimates are not addressed in the more recent versions of the national inventories as used in GFEI v2 (Table 2). The subsector emissions distribution for Canada in GFEI v2 shows a large

350 underestimate of gas transmission emissions compared to Lu21 but better agreement for gas production (Table S1 and S2). Qu21 agree with Lu21 for the US but find much lower emissions for Canada; this again likely reflects errors in satellite observations at high latitudes with spatial overlap between oil/gas and wetland emissions (Scarpelli et al., 2021a).

355 Lu21 and Qu21 find large underestimates of oil/gas emissions in the national inventory of Turkmenistan despite its use of oil production emission factors at the higher end of the IPCC range (Ministry of Nature Protection of 
Turkmenistan, 2015) (Fig. 3). This may reflect anomalous point sources from faulty operations (Varon et al., 2019, 2021; Barré et al. 2021).

360 Both inversions also show underestimates of Uzbekistan's gas emissions in all bottom-up inventories (Table 2 and Fig. 6), with the greatest underestimates in the south-central part of the country which contains most of the country's oil/gas production and gas processing infrastructure. The underestimate is larger for GFEI v2 than for GFEI v1 because it uses a more recent UNFCCC report (Uzhydromet, 2021) that estimates 37\% lower national oil/gas emissions. The IEA, EDGAR, and TRACE inventories are even lower than GFEI. The higher resolution results of Qu21 feature an offset between the underestimate in the south-central part of the country and a slight overestimate in the western part (Fig. S3). GFEI allocates most of Uzbekistan's gas transmission and processing emissions uniformly along pipelines due to a lack of facility data, and this may not properly account for the density of gas processing sources in central Uzbekistan.

370 Venezuela's emissions estimated by the inversions are much higher than any of the bottom-up inventories, and this may reflect venting and flaring of associated gas during oil production. Höglund-Isaksson et al. (2017) pointed out that bottom-up inventories often underestimate emissions of associated gas and that practices vary between countries. Despite increased gas collection efforts by the state-owned oil/gas company (República Bolivariana de Venezuela, 2017) and decreasing oil production for 2014-2019 (resulting in the decreasing emissions trend shown in Fig. 4) (EIA, 2021), Lu21 find little change in Venezuela's oil emissions over 2010-2017.

The inversions find that GFEI overestimates emissions around the Persian Gulf (Fig. S3), including large contributions from Iran and the UAE with high averaging kernel sensitivities in both inversions and smaller contributions from Qatar and Saudi Arabia. The overestimate in the UAE may reflect the nature of its oil production practices where there are a small number of high producing wells. The inversions find an overestimate of Iran's production emissions along the Persian Gulf including offshore emissions but an underestimate of oil/gas production emissions in northern Iran.

The overestimate of oil/gas production emissions in the Persian Gulf reflects a more general pattern of bottom-up inventories overestimating offshore oil/gas production emissions. Qu21 show an overestimate of offshore emissions in GFEI v1 for Côte d'Ivoire while Lu21 results are limited by the coarse resolution. Both inversions find overestimates of emissions in the South China Sea though averaging kernel sensitivities are low. Previous comparisons of top-down and bottom-up estimates found offshore emissions overestimated by bottom-up inventories in the North Sea (Bergamaschi et al., 2010) and Mexico (Shen et al., 2021; Zavala-Araiza et al., 2021). Individual countries may estimate offshore oil/gas production emissions using lower emission factors like those provided by the IPCC (2006), but these emissions are often aggregated in national reports making it difficult for GFEI to differentiate between onshore and offshore wells for spatial allocation of national emissions. 
Lu21 find lower emissions than the EDGAR v6, IEA, and Climate TRACE inventories for a number of countries country estimates are limited due to the coarse resolution for small countries like Kuwait an Qatar. Similar to these inventories, GFEI v2 overestimates emissions in Iraq based on the use of IPCC Tier 1 methods and in Nigeria based on its most recent UNFCCC report.

\section{Conclusions}

400 We have updated the Global Fuel Exploitation Inventory (GFEI) for methane emissions from the oil, gas, and coal sectors. GFEI is based on the national inventories reported by individual countries to the United Nations Framework Convention on Climate Change (UNFCCC), and spatially allocates emissions to infrastructure locations on a $0.1^{\circ} \mathrm{x}$ $0.1^{\circ}$ grid to support inversion of atmospheric methane observations. Our updated GFEI v2 inventory provides annual emissions for 2010-2019 based on recent country reports to the UNFCCC (2021), as well as new oil/gas well data and improved spatial information for Canada, Mexico, and China.

Russia's oil/gas emissions decrease by an order of magnitude in GFEI v2 relative to GFEI v1, while Nigeria's emissions increase by an order of magnitude, reflecting new emission factors used by the national inventories reported to the UNFCCC. Global oil emissions in GFEI v2 decrease from 2010 to 2019 driven in large part by Iran,

410 Libya, and Venezuela. Global gas emissions decrease from 2010 to 2017, mostly driven by Russia, but then increase in 2018 and 2019. Global coal emissions show mixed trends over the time period, mainly driven by China but with sustained decreases in the US and increases in Russia. GFEI v2 emissions for all sectors are lower than the EDGAR (v6) and IEA inventories though there is considerable variability for individual countries.

415 We compared GFEI oil/gas emissions to the results of global inversions of satellite (GOSAT) and in situ (GLOBALVIEWplus) observations of atmospheric methane. These inversions find that GFEI oil/gas emissions are underestimated for the US, Venezuela (oil), Uzbekistan (gas), Canada, and Turkmenistan, leading to an underestimate of global gas emissions. Global oil emissions are overestimated in GFEI v1 compared to inversion results, mostly due to Russia. The inversions support the downward revision of Russian emissions in its national inventory but not the increase in Nigerian emissions.

There is considerable interest in using satellite observations of atmospheric methane to evaluate and improve the national inventories used for climate policy. The scope of this work was limited by the sparsity of the GOSAT observations and the coarse resolution of the global inversions. New satellite observations from TROPOMI now provide much higher data density though there are still large regional biases in the early-generation methane retrievals (Qu et al., 2021). As the TROPOMI data improve (Lorente et al., 2021), they will prompt finer-resolution inversions to better quantify emissions on national scales and resolve the regional contributions from individual activities. Inverse analyses of TROPOMI data to evaluate the national methane emission inventories reported by 
individual countries to the UNFCCC, as enabled here by the GFEI spatial gridding, may enable efficient monitoring of national methane emissions from space in pursuit of climate policy.

Data/Code availability. GFEI v2 emission grids for 2019 by sector and subsector are available for download from the Harvard Dataverse at https://doi.org/10.7910/DVN/HH4EUM (Scarpelli et al., 2021b). The 2010-2018 emission grids are available upon request. The code used for inventory creation is available upon reasonable request.

Author contributions. TRS and SG compiled the datasets and created the inventory with assistance from MPS. DJJ conceived of and provided guidance for the project. $\mathrm{XL}, \mathrm{ZQ}$, and $\mathrm{YZ}$ provided inversion data and assisted with data analysis. FR and DG provided TRACE inventory data and feedback on interpretation. TRS prepared the manuscript with contributions from all coauthors.

Competing interests. The authors declare that they have no conflict of interest.

Acknowledgements. This work was funded by the NASA Carbon Monitoring System, the NASA Advanced Information Systems Technology (AIST) Program, a National Defense Science and Engineering Graduate

Fellowship (NDSEG) to TRS, and funding from the NSFC (42007198) for YZ.

\section{References}

Alvarez, R. A., Zavala-Araiza, D., Lyon, D. R., Allen, D. T., Barkley, Z. R., Brandt, A. R., Davis, K. J., Herndon, S. C., Jacob, D. J., Karion, A., Kort, E. A., Lamb, B. K., Lauvaux, T., Maasakkers, J. D., Marchese, A. J., Omara, M., Pacala, S. W., Peischl, J., Robinson, A. L., Shepson, P. B., Sweeney, C., Townsend-Small, A., Wofsy, S. C., and Hamburg, S. P.: Assessment of methane emissions from the U.S. oil and gas supply chain, Science, 361, 186,2018

Atherton, E., Risk, D., Fougère, C., Lavoie, M., Marshall, A., Werring, J., Williams, J. P., and Minions, C.: Mobile measurement of methane emissions from natural gas developments in northeastern British Columbia, Canada, Atmos. Chem. Phys., 17, 12405-12420, 2017.

Baray, S., Darlington, A., Gordon, M., Hayden, K. L., Leithead, A., Li, S. M., Liu, P. S. K., Mittermeier, R. L., Moussa, S. G., O'Brien, J., Staebler, R., Wolde, M., Worthy, D., and McLaren, R.: Quantification of methane sources in the Athabasca Oil Sands Region of Alberta by aircraft mass balance, Atmos. Chem. Phys., 18, 7361$7378,2018$.

Baray, S., Jacob, D. J., Massakkers, J. D., Sheng, J. X., Sulprizio, M. P., Jones, D. B. A., Bloom, A. A., and McLaren, R.: Estimating 2010-2015 Anthropogenic and Natural Methane Emissions in Canada using ECCC Surface and GOSAT Satellite Observations, Atmos. Chem. Phys. Discuss., 2021, 1-40, 2021.

Barré, J., Aben, I., Agustí-Panareda, A., Balsamo, G., Bousserez, N., Dueben, P., Engelen, R., Inness, A., Lorente, A., McNorton, J., Peuch, V. H., Radnoti, G., and Ribas, R.: Systematic detection of local $\mathrm{CH}_{4}$ anomalies by combining satellite measurements with high-resolution forecasts, Atmos. Chem. Phys., 21, 5117-5136, 2021.

Bergamaschi, P., Krol, M., Meirink, J. F., Dentener, F., Segers, A., van Aardenne, J., Monni, S., Vermeulen, A. T., Schmidt, M., Ramonet, M., Yver, C., Meinhardt, F., Nisbet, E. G., Fisher, R. E., O'Doherty, S., and Dlugokencky, E. J.: Inverse modeling of European $\mathrm{CH}_{4}$ emissions 2001-2006, J. Geophys. Res.: Atmospheres, 115,2010 . 
Bergamaschi, P., Frankenberg, C., Meirink, J. F., Krol, M., Villani, M. G., Houweling, S., Dentener, F., Dlugokencky, E. J., Miller, J. B., Gatti, L. V., Engel, A., and Levin, I.: Inverse modeling of global and regional $\mathrm{CH}_{4}$ emissions using SCIAMACHY satellite retrievals, J. Geophys. Res., 114, D22301, https://doi.org/10.1029/2009JD012287, 2009.

Bloom, A. A., Bowman, K. W., Lee, M., Turner, A. J., Schroeder, R., Worden, J. R., Weidner, R., McDonald, K. C., and Jacob, D. J.: A global wetland methane emissions and uncertainty dataset for atmospheric chemical transport models (WetCHARTs version 1.0), Geosci. Model Dev., 10, 2141-2156, https://doi.org/10.5194/gmd10-2141-2017, 2017.

Calisesi, Y., Soebijanta, V. T., and van Oss, R.: Regridding of remote soundings: Formulation and application to ozone profile comparison, J. Geophys. Res., 110, http://doi.org/10.1029/2005jd006122, 2005.

Center for International Earth Science Information Network - CIESIN - Columbia University: Gridded Population of the World, Version 4.11 (GPWv4.11), Population Count Adjusted to Match 2015 Revision of UN WPP Country Totals, Revision 11. NASA Socioeconomic Data and Applications Center (SEDAC), Palisades, NY, available at: https://doi.org/10.7927/H4PN93PB, 2017.

485 Chan, E., Worthy, D. E. J., Chan, D., Ishizawa, M., Moran, M. D., Delcloo, A., and Vogel, F.: Eight-Year Estimates of Methane Emissions from Oil and Gas Operations in Western Canada Are Nearly Twice Those Reported in Inventories, Environmental Science \& Technology, 54, 14899-14909, 2020.

Conference of the Parties (COP): Nationally determined contributions under the Paris Agreement: Synthesis report by the secretariat, Glasgow, 1-12 November 2021, FCCC/PA/CMA/2021/2, last access: March 2021, https://unfccc.int/documents/268571, 2021.

Conference of the Parties (COP): Nationally determined contributions under the Paris Agreement: Synthesis report by the secretariat, Marrakech, 2 May 2016, FCCC/CP/2016/2, last access: March 2021, https://unfccc.int/documents/268571, 2016.

Crippa, M., Guizzardi, D., Muntean, M., Schaaf, E., Lo Vullo, E., Solazzo, E., Monforti-Ferrario, F., Olivier, J., Vignati, E.: EDGAR v6.0 Greenhouse Gas Emissions, European Commission, Joint Research Centre (JRC), http://data.europa.eu/89h/97a67d67-c62e-4826-b873-9d972c4f670b, 2021.

Cui, Y. Y., Henze, D. K., Brioude, J., Angevine, W. M., Liu, Z., Bousserez, N., Guerrette, J., McKeen, S. A., Peischl, J., Yuan, B., Ryerson, T., Frost, G., and Trainer, M.: Inversion estimates of lognormally distributed methane emission rates from the Haynesville-Bossier oil and gas production region using airborne measurements, J. Geophys. Res., 124, 3520-3531, http://doi.org/10.1029/2018jd029489, 2019.

Defra and BEIS: National Atmospheric Emissions Inventory, Crown copyright 2021 under the Open Government Licence (OGL), last access: July 2021, available at: http://naei.beis.gov.uk/, 2021.

EIA: International Energy Statistics, last access: September 2021, https://www.eia.gov/international/data/world, 2021.

505 Enverus: Enverus International, last access: December 2019, http://drillinginfo.com/, 2019.

EPA: Inventory of U.S. greenhouse gas emissions and sinks: 1990-2018, last access: May 2020, https://www.epa.gov/ghgemissions/us-greenhouse-gas-inventory-report-archive, 2020.

EPA: Inventory of U.S. greenhouse gas emissions and sinks: 1990-2019, last access: September 2021, https://www.epa.gov/ghgemissions/inventory-us-greenhouse-gas-emissions-and-sinks-1990-2019, 2021.

510 European Commission: Joint EU-US Statement on the Global Methane Pledge, Brussels, October 11, last access: October 2021, available at: https://ec.europa.eu/commission/presscorner/detail/en/statement_21_5206, 2021. 
European Commission: Emission Database for Global Atmospheric Research (EDGAR), release version 6, last access: September 2021, available at: https://edgar.jrc.ec.europa.eu/index.php/dataset_ghg60, 2021.

European Commission: Emission Database for Global Atmospheric Research (EDGAR), release version 4.3.2, last access: June 2018, available at: https://edgar.jrc.ec.europa.eu/report 2017, 2017.

Federal Republic of Nigeria: Third National Communication (TNC) of the Republic of Nigeria, Federal Ministry of Environment, last access: March 2021, https://unfccc.int/non-annex-I-NCs, 2020.

Hiller, R. V., Bretscher, D., DelSontro, T., Diem, T., Eugster, W., Henneberger, R., Hobi, S., Hodson, E., Imer, D., Kreuzer, M., Künzle, T., Merbold, L., Niklaus, P. A., Rihm, B., Schellenberger, A., Schroth, M. H., Schubert, C. J., Siegrist, H., Stieger, J., Buchmann, N., and Brunner, D.: Anthropogenic and natural methane fluxes in Switzerland synthesized within a spatially explicit inventory, Biogeosciences, 11, 1941-1959, https://doi.org/10.5194/bg-11-1941-2014, 2014.

Höglund-Isaksson, L.: Bottom-up simulations of methane and ethane emissions from global oil and gas systems 1980 to 2012, Environmental Research Letters, 12, 024007, 2017.

Houweling, S., Bergamaschi, P., Chevallier, F., Heimann, M., Kaminski, T., Krol, M., Michalak, A. M., and Patra, P.: Global inverse modeling of $\mathrm{CH}_{4}$ sources and sinks: an overview of methods, Atmos. Chem. Phys., 17, 235256, https://doi.org/10.5194/acp-17-235-2017, 2017.

Hu, H., Landgraf, J., Detmers, R., Borsdorff, T., Aan de Brugh, J., Aben, I., Butz, A., and Hasekamp, O.: Toward Global Mapping of Methane With TROPOMI: First Results and Intersatellite Comparison to GOSAT, Geophys. Res. Lett., 45, 3682-3689, https://doi.org/10.1002/2018g1077259, 2018.

IEA: Methane Tracker Database, International Energy Agency, Paris, last access: January 2021, https://www.iea.org/articles/methane-tracker-database, 2021.

IPCC: 2019 Refinement to the 2006 IPCC Guidelines for National Greenhouse Gas Inventories. Calvo Buendia, E., Tanabe, K., Kranjc, A., Jamsranjav, B., Fukuda, M., Ngarize, S., Osako, A., Pyrozhenko, Y., Shermanau, P., and Federici, S. (Eds.), IPCC, Switzerland, 2019.

IPCC: 2006 IPCC guidelines for national greenhouse gas inventories, prepared by the national greenhouse gas inventories program. Eggleston, H. S., Buendia, L., Miwa, K., Ngara, T., and Tanabe, K. (Eds.), IPCC, Hayama, Japan, 2006.

Jacob, D. J., Turner, A. J., Maasakkers, J. D., Sheng, J., Sun, K., Liu, X., Chance, K., Aben, I., McKeever, J., and Frankenberg, C.: Satellite observations of atmospheric methane and their value for quantifying methane emissions, Atmos. Chem. Phys.,16, 14371-96, 2016.

Janssens-Maenhout, G., Crippa, M., Guizzardi, D., Muntean, M., Schaaf, E., Dentener, F., Bergamaschi, P., Pagliari, V., Olivier, J.G. J., Peters, J. A. H. W., van Aardenne, J. A., Monni, S., Doering, U., Petrescu, A. M. R., Solazzo, E., and Oreggioni, G. D.: EDGAR v4.3.2 Global Atlas of the three major greenhouse gas emissions for the period 1970-2012, Earth Syst. Sci. Data, 11, 959-1002, https://doi.org/10.5194/essd-11-959-2019, 2019.

Johnson, M. R., Tyner, D. R., Conley, S., Schwietzke, S., and Zavala-Araiza, D.: Comparisons of Airborne Measurements and Inventory Estimates of Methane Emissions in the Alberta Upstream Oil and Gas Sector, Environ. Sci. \& Tech., 51, 13008-13017, 2017.

Lorente, A., Borsdorff, T., Butz, A., Hasekamp, O., aan de Brugh, J., Schneider, A., Wu, L., Hase, F., Kivi, R., Wunch, D., Pollard, D. F., Shiomi, K., Deutscher, N. M., Velazco, V. A., Roehl, C. M., Wennberg, P. O., Warneke, T., Landgraf, J.: Methane retrieved from TROPOMI: improvement of the data product and validation of the first 2 years of measurements, Atmos. Meas. Tech., 14, 665-684, https://doi.org/10.5194/amt-14-6652021, 2021. 
Lu, X., Jacob, D. J., Zhang, Y., Maasakkers, J. D., Sulprizio, M. P., Shen, L., Qu, Z., Scarpelli, T. R., Nesser, H., Yantosca, R. M., Sheng, J., Andrews, A., Parker, R. J., Boesch, H., Bloom, A. A., and Ma, S.: Global methane budget and trend, 2010-2017: complementarity of inverse analyses using in situ (GLOBALVIEWplus $\mathrm{CH}_{4}$ ObsPack) and satellite (GOSAT) observations, Atmos. Chem. Phys., 21, 4637-4657, 2021.

Maasakkers, J. D., Jacob, D. J., Sulprizio, M. P., Turner, A. J., Weitz, M., Wirth, T., Hight, C., DeFigueiredo, M., Desai, M., Schmeltz, R., Hockstad, L., Bloom, A. A., Bowman, K. W., Jeong, S., and Fischer, M. L.: Gridded National Inventory of U.S. Methane Emissions, Environ. Sci. Technol., 50, 13123-13133, 2016.

Maasakkers, J. D., Jacob, D. J., Sulprizio, M. P., Scarpelli, T. R., Nesser, H., Sheng, J., Zhang, Y., Hersher, M., Bloom, A. A., Bowman, K. W., Worden, J. R., Janssens-Maenhout, G., and Parker, R. J.: Global distribution of methane emissions, emission trends, and $\mathrm{OH}$ concentrations and trends inferred from an inversion of GOSAT satellite data for 2010-2015, Atmos. Chem. Phys., 19, 7859-7881, http://doi.org/10.5194/acp-19-7859-2019, 2019.

Maasakkers J. D., Jacob, D. J., Sulprizio, M. P., Scarpelli, T. R., Nesser, H., Sheng, J., Zhang, Y., Lu, X., Bloom, A. A., Bowman, K. W., Worden, J. R., and Parker, R. J.: 2010-2015 North American methane emissions, sectoral contributions, and trends: a high-resolution inversion of GOSAT satellite observations of atmospheric methane, Atmos. Chem. Phys., 21, 4339-4356, https://doi.org/10.5194/acp-21-4339-2021, 2021.

MacKay, K., Lavoie, M., Bourlon, E., Atherton, E., O’Connell, E., Baillie, J., and Fougère, C.: Risk, D. Methane Emissions from Upstream Oil and Gas Production in Canada Are Underestimated, Sci. Rep., 11, 8041, https://doi.org/10.1038/s41598-021-87610-3, 2021.

Ministry of Nature Protection of Turkmenistan: Third national communication of Turkmenistan under the United Nations Framework Convention on Climate Change (UNFCCC), last access: July 2021, https://unfccc.int/nonannex-I-NCs, 2015.

MINSEDD (Ministère de la Salubrité, de l'Environnement et du Développement Durable): Rapport de la troisième communication nationale (TCN) de la Côte d'Ivoire dans le cadre de la convention cadre des nations unies sur les changements climatiques (CCNUCC), last access: July 2021, https://unfccc.int/non-annex-I-NCs, 2017.

NOAA ESRL: Cooperative Global Atmospheric Data Integration Project: Multi-laboratory compilation of atmospheric methane data for the period 1957-2017, obspack_ch4_1_GLOBALVIEWplus_v1.0_2019_01_08, Earth System Research Laboratory, Global Monitoring Laboratory, $\overline{\mathrm{http}}$ ://dx.doi.org/10.25925/2019010, 2019.

Omara, M., Zimmerman, N., Sullivan, M. R., Li, X., Ellis, A., Cesa, R., Subramanian, R., Presto, A. A., Robinson, A. L.: Methane emissions from natural gas production sites in the United States: Data synthesis and national estimate, Environ. Sci. Tech., 52, 12915-12925, http://doi.org/ 10.1021/acs.est.8b03535, 2018.

585 Parker, R. J., Webb, A., Boesch, H., Somkuti, P., Barrio Guillo, R., Di Noia, A., Kalaitzi, N., Anand, J., Bergamaschi, P., Chevallier, F., Palmer, P. I., Feng, L., Deutscher, N. M., Feist, D. G., Griffith, D. W. T., Hase, F., Kivi, R., Morino, I., Notholt, J., Oh, Y.-S., Ohyama, H., Petri, C., Pollard, D. F., Roehl, C., Sha, M. K., Shiomi, K., Strong, K., Sussmann, R., Te, Y., Velazco, V. A., Warneke, T., Wennberg, P. O., and Wunch, D.: A Decade of GOSAT Proxy Satellite $\mathrm{CH}_{4}$ Observations, Earth Syst. Sci. Data, 12, 3383-3412, https://doi.org/10.5194/essd-12-3383-2020, 2020.

Qu, Z., Jacob, D. J., Shen, L., Lu, X., Zhang, Y., Scarpelli, T. R., Nesser, H. O., Sulprizio, M. P., Maasakkers, J. D., Bloom, A. A., Worden, J. R., Parker, R. J., and Delgado, A. L.: Global distribution of methane emissions: a comparative inverse analysis of observations from the TROPOMI and GOSAT satellite instruments, Atmos. Chem. Phys. Discuss. (preprint), https://doi.org/10.5194/acp-2021-309, in review, 2021. Unidas sobre Cambio Climático, last access: June 2019, https://unfccc.int/non-annex-I-NCs, 2017. 
Reuland, F., Puthuparambil, S., Kumble, S., Kirk, T., Muralidharan, R., Rabbani, M., Ayandele, E., Diaz, K., Wang, R., Owens, L., and Gordon, D.: Oil and gas, version 1: oil and gas production and refining, the Rocky Mountain Institute (RMI), Boulder, Colorado, USA, Climate TRACE Emissions Inventory, https://climatetrace.org, 2021.

600

Rodgers, C. D.: Inverse methods for atmospheric sounding: Theory and Practice, Series on Atmospheric, Oceanic, and Planetary Physics - Vol. 2, World Scientific Publishing Co. Pte. Ltd., Singapore, https://doi.org/10.1142/3171, 2000.

Russian Federation, The: National Inventory Report: Anthropogenic emissions from sources and absorption by sinks greenhouse gases not regulated by the Montreal Protocol for 1990 - 2019 Part 1, last access: September 2021, https://unfccc.int/ghg-inventories-annex-i-parties/2021, 2021.

Russian Federation, The: National Inventory Report: Anthropogenic emissions from sources and absorption by sinks greenhouse gases not regulated by the Montreal Protocol for 1990 - 2016 Part 1, last access: July 2021, https://unfccc.int/.../national-inventory-submissions-2018, 2018.

610 Rutherford, J. S., Sherwin, E. D., Ravikumar, A. P., Heath, G. A., Englander, J., Cooley, D., Lyon, D., Omara, M., Langfitt, Q., Brandt, A. R.: Closing the methane gap in US oil and natural gas production emissions inventories, Nature Communications, 12, 4715, https://doi.org/10.1038/s41467-021-25017-4, 2021.

Saunois, M., Stavert, A. R., Poulter, B., Bousquet, P., Canadell, J. G., Jackson, R. B., Raymond, P. A., Dlugokencky, E. J., Houweling, S., Patra, P. K., Ciais, P., Arora, V. K., Bastviken, D., Bergamaschi, P., Blake, 615 D. R., Brailsford, G., Bruhwiler, L., Carlson, K. M., Carrol, M., Castaldi, S., Chandra, N., Crevoisier, C., Crill, P. M., Covey, K., Curry, C. L., Etiope, G., Frankenberg, C., Gedney, N., Hegglin, M. I., Höglund-Isaksson, L., Hugelius, G., Ishizawa, M., Ito, A., Janssens-Maenhout, G., Jensen, K. M., Joos, F., Kleinen, T., Krummel, P. B., Langenfelds, R. L., Laruelle, G. G., Liu, L., Machida, T., Maksyutov, S., McDonald, K. C., McNorton, J., Miller, P. A., Melton, J. R., Morino, I., Müller, J., Murguia-Flores, F., Naik, V., Niwa, Y., Noce, S., O'Doherty, 620 S., Parker, R. J., Peng, C., Peng, S., Peters, G. P., Prigent, C., Prinn, R., Ramonet, M., Regnier, P., Riley, W. J., Rosentreter, J. A., Segers, A., Simpson, I. J., Shi, H., Smith, S. J., Steele, L. P., Thornton, B. F., Tian, H., Tohjima, Y., Tubiello, F. N., Tsuruta, A., Viovy, N., Voulgarakis, A., Weber, T. S., van Weele, M., van der Werf, G. R., Weiss, R. F., Worthy, D., Wunch, D., Yin, Y., Yoshida, Y., Zhang, W., Zhang, Z., Zhao, Y., Zheng, B., Zhu, Q., Zhu, Q., and Zhuang, Q.: The Global Methane Budget 2000-2017, Earth Syst. Sci. Data, $12,1561-1623,2020$.

Scarpelli, T. R., Jacob, D. J., Moran, M., Gordon, D., and Reuland, F.: A gridded inventory of Canada's anthropogenic methane emissions, Environmental Research Letters (submitted), 2021 a.

Scarpelli, T. R., and Jacob, D. J.: Global Fuel Exploitation Inventory (GFEI), Harvard Dataverse, V2, https://doi.org/10.7910/DVN/HH4EUM, 2021b.

Scarpelli, T. R., Jacob, D. J., Maasakkers, J. D., Sulprizio, M. P., Sheng, J. X., Rose, K., Romeo, L., Worden, J. R., and Janssens-Maenhout, G.: A global gridded $(0.1 \circ \times 0.1 \circ)$ inventory of methane emissions from oil, gas, and coal exploitation based on national reports to the United Nations framework convention on climate change, Earth Syst. Sci. Data, 12, 563-75, 2020a.

Scarpelli, T.R., Jacob, D.J., Octaviano Villasana, C. A., Ramírez Hernández, I. F., Cárdenas Moreno, P. R., Cortés Alfaro, E. A., García García, M. Á., and Zavala-Araiza, D.: A gridded inventory of anthropogenic methane emissions from Mexico based on Mexico's national inventory of greenhouse gases and compounds, Environ. Res. Lett., 15, 105015, https://doi.org/10.1088/1748-9326/abb42b, 2020 b.

Shen, L., Zavala-Araiza, D., Gautam, R., Omara, M., Scarpelli, T., Sheng, J., Sulprizio, M. P., Zhuang, J., Zhang, Y., Lu, X., Hamburg, S. P., and Jacob, D. J.: Unravelling a large methane emission discrepancy in Mexico using satellite observations, Remote Sens. of Environ., 260, 112461, https://doi.org/10.1016/j.rse.2021.112461, 2021. 
Sheng, J., Jacob, D. J., Maasakkers, J. D., Sulprizio, M. P., Zavala-Araiza, D., and Hamburg, S. P.: A highresolution $\left(0.1^{\circ} \times 0.1^{\circ}\right)$ inventory of methane emissions from Canadian and Mexican oil and gas systems, Atmos. Environ., 158, 211-215, https://doi.org/10.1016/j.atmosenv.2017.02.036, 2017.

Sheng, J., Song, S., Zhang, Y., Prinn, R. G., and Janssens-Maenhout, G.: Bottom-up estimates of coal mine methane emissions in China: A gridded inventory, emission factors, and trends, Environ. Sci. Technol. Lett., 6, 8, 473478, https://doi.org/10.1021/acs.estlett.9b00294, 2019.

Tyner, D. R., and Johnson, M. R.: Where the methane is - insights from novel airborne LiDAR measurements combined with ground survey data, Environ. Sci. Tech., 55, 14, 9773-9783, https://doi.org/10.1021/acs.est.1c01572, 2021.

UNFCCC: Greenhouse Gas Inventory Data Interface, last access: September 2021, http://di.unfecc.int/detailed data by party, 2021.

Uzhydromet: The first biennial update report of the Republic of Uzbekistan under the UN Framework Convention on Climate Change, Center of Hydrometeorological Service of the Republic of Uzbekistan (Uzhydromet), last access: September 2021, https://unfccc.int/BURs, 2021.

Varon, D. J., McKeever, J., Jervis, D., Maasakkers, J. D., Pandey, S., Houweling, S., et al.: Satellite discovery of anomalously large methane point sources from oil/gas production. Geophysical Research Letters, 46, 1350713516, https://doi.org/10.1029/2019GL083798, 2019.

Varon, D. J., Jervis, D., McKeever, J., Spence, J., Gains, D., and Jacob, D. J.: High-frequency monitoring of anomalous methane point sources with multispectral Sentinel-2 satellite observations, Atmos. Meas. Tech., 14, 2771-2785, https://doi.org/10.5194/amt-14-2771-2021, 2021.

Wang, Y.-P. and Bentley, S.: Development of a spatially explicit inventory of methane emissions from Australia and its verification using atmospheric concentration data, Atmos. Environ., 36, 4965-4975, 2002.

Western, L. M., Ramsden, A. E., Ganesan, A. L., Boesch, H., Parker, R. J., Scarpelli, T. R., Tunnicliffe, R. L., and Rigby, M.: Estimates of North African methane emissions from 2010-2017 using GOSAT observations, Environ. Sci. Technol. Lett., Article ASAP, https://doi.org/10.1021/acs.estlett.1c00327, 2021.

Zhang, Y., Jacob, D. J., Lu, X., Maasakkers, J. D., Scarpelli, T. R., Sheng, J.-X., Shen, L., Qu, Z., Sulprizio, M. P., Chang, J., Bloom, A. A., Ma, S., Worden, J., Parker, R. J., and Boesch, H.: Attribution of the accelerating increase in atmospheric methane during 2010-2018 by inverse analysis of GOSAT observations, Atmos. Chem. Phys., 21, 3643-3666, https://doi.org/10.5194/acp-21-3643-2021, 2021. Houweling, S., Kort, E. A., Maasakkers, J. D., Molina, L. T., Pusuluri, A., Scarpelli, T., Schwietzke, S., Shen, L., Zavala, M., and Hamburg, S. P.: A tale of two regions: methane emissions from oil and gas production in offshore/onshore Mexico, Environ. Res. Lett., 16, 024019, 2021. 